\title{
EEN MERKWAARDIGE BRIEF
}

DOOR

R. D. Simons

In 1924 werd door de Gouverneur van Suriname, A. J. A. A. baron van Heemstra, het groot-opperhoofd der SaramaccanerBosnegers Jankoeso naar Paramaribo ontboden ten einde verschillende zaken te bespreken.

Onder allerlei voorwendsels gaf Jankoeso aan herhaalde oproepingen geen gehoor, waarna aan de bosopzichter Junker, gesteund door een militaire patrouille onder de 1ste luitenant Dahler, opdracht werd gegeven Jankoeso naar Paramaribo te geleiden.

Op 5 April 1924 had ten Gouvernementshuize een bijeenkomst plaats, waarbij vele burgerlijke en militaire autoriteiten aanwezig waren. Jankoeso erkende toen, dat zijn niet gevolg geven aan de oproepingen een gevolg was van onwil zijnerzijds.

Gouverneur van Heemstra overwoog in een beschikking van dezelfde dag, dat het ogenblik van onderhandelen met Jankoeso voorbij was, en dat ter uitvoering van het met zijn stam op 13 December 1835 gesloten tractaat de door de Gouverneur gewenste maatregelen zonder meer als plicht aan dit groot-opperhoofd zouden worden opgelegd.

Deze beschikking is onder het hoofd: „Een interessante beschikking van den Gouverneur van Suriname" te vinden in De West-Indische Gids, 6de jaargang 1924/1925 blz. 238.

Hieraan kunnen wij thans het volgende toevoegen:

Men meende indertijd, dat familieleden van Jankoeso op het dorp Kapasiekélé hem hadden aangezet tot of gestijfd in zijn weigering naar Paramaribo te gaan.

Bij het onderzoek deelden deze aan lt. Dahler mee, dat dit dit niet het geval was geweest, doch dat zij integendeel bij een brief, namens hen door de zendeling der Ev. Broedergemeente geschreven, bij Jankoeso er op hadden aangedrongen aan de oproepingen naar Paramaribo te gaan gevolg te geven. 
Dit bleek inderdaad juist. De brief was nog in het bezit van Jankoeso en werd aan lt. Dahler ter hand gesteld. Lt. Dahler stond ons deze brief af voor onze verzameling Surinamensia.

$\mathrm{Na}$ de interessante beschikking van 1924 vinde deze ook interessante brief na 25 jaar zijn eerste publicatie. Daaraan voegen wij een letterlijke vertaling in het Nederlands toe.

DE BRIEF AAN JANKOESO.

Kapasiekélé 22-3-1924.

Lobbi Granman! (Groot-Opperhoofd)

$\mathrm{Na}$ ini disi brifi wi alla, familie vo Kapasiekélé seni taki joe bigi odi en wi seni aksi va joe tan. Ma wi seni piki joe tki wi no de boen; wan bigi voega miti wi voe joe hede. Den bakra kisi Dahomie tjari go na foto strafoe en wi jere taki den wani kon kisi heli Kapasiekélé tjari go wi na strafoe.

Alla den sani disi de miti wi vo joe hede, bekasi joe wani kom na den bakra vo taki nanga den. Dati hede wisenibegi joe, tangi tangi, joe moe kom hesi meki den bakra sa loesoe wi, joe moe kom hesi, no drai moro.

Bikasi trawiki den kisi Boikonie toe. Ma joe no moe denki taki na wan trobi den wani meki nanga joe ma na di joe no wani kom na foto nomo.

Dus joe sabi alla san kaba, dahede joe moe kom, wi de wakti taki joe sa kom passa go na foto.

Wi de den familie voe joe vo Kapasiekélé,

Fransieman.

Baito.

VERTALING

Kapasiekélé 22-3-1924.

Geliefde Granman! (Gouverneur)

In deze brief laten wij allen, familie van Kapasiekélé, U zeer groeten en wij laten vragen hoe het U gaat. Maar wij laten U weten, dat het ons niet goed gaat; een grote moeilijkheid heeft ons getroffen om uwentwil, door uw schuld. De Blanken (sc. de autoriteiten) hebben Dahomie gevangen genomen(en) naar de stad gebracht om straf te ondergaan en wij horen, dat zij geheel Kapasiekélé willen komen halen om ons te straffen.

$\mathrm{Al}$ deze dingen overkomen ons door $\mathrm{U}$ omdat $\mathrm{U}$ niet bij de 
Blanken wilt komen om met hen te spreken. Daarom laten wij $U$ verzoeken, aljeblieft alsjeblieft, gij moet gauw komen opdat de Blanken ons zullen loslaten, ge moet komen, draal niet langer. Want verleden week hebben ze ook Boikonie gevangen genomen. Maar ge moet niet denken, dat zij met $\mathrm{U}$ onaangenaamheden willen maken, maar het is alleen omdat gij niet in de stad (Paramaribo) wilt komen.

Dus ge weet reeds alles wat er gebeurd is, daarom moet ge komen, wij wachten dat ge langs zult komen gaande naar de stad.

Wij zijn de familieleden van U van Kapasiekélé.

Fransieman.

Baito. 